\title{
The impact of excessive irrigation water and fertilizers on the environment and groundwater quality in arid regions
}

\author{
H. M. Al-Ghobari \\ Agric. Eng. Dept., College of Food and Agriculture Sciences, \\ King Saud University, Riyadh, Saudi Arabia
}

\begin{abstract}
The main source of water in the Najran region is the unconfined shallow aquifer along the Najran Wadi (valley). Ground water quality of the Najran region was studied in 43 well water samples collected from different wells in the region. Water samples were chemically analyzed and evaluated using water quality criteria. The investigated water quality parameters revealed the following: water salinity $\left(\mathrm{EC}_{\mathrm{w}} \mathrm{dS} \mathrm{m} \mathrm{m}^{-1}\right)$ ranged from 0.35 to $5.99 \mathrm{dS} \mathrm{m}^{-1}$ (i.e. 227 to $3843 \mathrm{meq} / \mathrm{l}$ ) with an average of $1.95 \mathrm{dS} \mathrm{m}^{-1}$ (i.e. $1248 \mathrm{meq} / \mathrm{l}$ ), $\mathrm{pH}$ value ranged from 7.28-7.80 with an average of 7.55. The dominant cation was $\mathrm{Ca}$ followed by $\mathrm{Na}, \mathrm{Mg}$ and $\mathrm{K}$ while $\mathrm{Cl}$ was the dominant anion followed by $\mathrm{HCO}_{-3}$ with an average of 432.4 and $180.2 \mathrm{meq} / \mathrm{l}$, respectively. The suitability of this water for irrigation was slight to moderate saline water.

Also, " $48.8 \%$ " of the water had salinity above the recommended level for drinking water. The values of adjusted sodium adsorption ratio (adj. SAR) and residual sodium carbonate (RSC) were in the range of 0.53 to 17.22 and -1.69 to -41.85 with an average of 4.17 and -12.94 meq/l, respectively. These results indicated no expected problems with either sodium or permeability from most of the studied wells. Concentration of $\left(\mathrm{NO}_{3}-\mathrm{N}\right)$ ranged from 0.30 to $33.1 \mathrm{meq} / 1$ with an average of $9.48 \mathrm{meq} / \mathrm{l}$. All the tested samples have $\left(\mathrm{NO}_{3}-\mathrm{N}\right)$ concentrations lower than the recommended level for drinking water.

Also, it was found that in the Najran region a large fraction of farms (more than $35 \%$ ) which have been equipped with tube wells and irrigation systems have abandoned business and farming as a result of groundwater depletion, this is because the annual groundwater discharge far exceeds the recharge. The excessive extraction of groundwater resources have caused that water for human
\end{abstract}


consumption and agriculture has become an increasingly scarce, which resulted with detrimental effects on the environment by desertification and climate change, especially in Saudi Arabia experiencing drought and hot and dry climate. Keywords: groundwater, water quality, extraction, environment, Najran.

\section{Introduction}

The demand for water is not static. It continues to grow as the population increases and living standards improve, and water is becoming scarce not only in arid and drought prone areas but also in regions where rainfall is abundant. During the last century, advances in agricultural science and technology have profoundly affected our standard of living and way of life. Agricultural chemicals are an important component of these advances. They contribute substantially to the productivity and efficiency of agriculture and to the wellbeing of rural and urban communities. Even so, many people are concerned about the possible risks to human health, water quality, and a safe environment resulting from the use of those chemicals. Hence, the quality and quantity of water is a matter of great concern in the world and in particular in arid and semiarid regions.

There are many parameters to be considered in evaluating quality of irrigation water. The main factors as reported by Ayers [1] are: salinity, relative amount of sodium, and the other parameters. Many water quality factors have been considered in order to classify and evaluate the water suitability for irrigation. The influence of the chemical characteristics of water on soil characteristics have been investigated by many researchers including Richards [2], Doneen [3], Rhoades [4], Oster and Rhoades [5], Oster and Schroer [6], Bielorai et al. [7], Bhivare and Nimbalkar [8], Moolman [9], Al Ruwaih et al. [10] and AlKharabshesh [11].

With growing population, urbanization and irrigated agriculture in arid regions in general and in Saudi Arabia in particular, water shortages are increasing. A major development and progress have been achieved in the agricultural sector in the last 20-30 years in Saudi Arabia. This is because during the late 1970s and early 1980s, the Saudi government offered free agricultural lands, free-interest loans and farming and investment subsidies for each citizen interested in farming and agriculture. This increased drastically the areas irrigated and hence, the number of wells and the excessive groundwater pumping for irrigation demand. Nowadays agriculture irrigation is the single, largest water demand in the Kingdom of Saudi Arabia accounting for $85-90 \%$ of consumptive use (MOP, 2000). This increased drastically the number of wells and the excessive groundwater pumping for irrigation demand. The excessive extraction of groundwater resources and their resulting problems have influenced the groundwater quality, quantity and the number of wells and farms in each agricultural region in the country, such as, the Najran region.

With this fast development of agricultural activities in the country, it has become imperative to study the water quality to assess the chemical characteristics of ground water for the sustainable agriculture management and 
raising productivity. Several studies were conducted in order to evaluate water quality for irrigation in some areas of the Kingdom of Saudi Arabia, such as, Hamza et al. [12], Ayed and Mashhady [13], Mashhady and Yousef [14], Etewy et al. [15], Mee [16], Al-Omran [17], Bazuhair and Alkaff [18], Hussain and Sadiq [19], Al-Ghobari [20], Al-Jaloud and Hussain [21], Al-Jaloud [22] and Abdel-Aal et al. [23]. Most of these studies were concentrated in the central and eastern regions of Saudi Arabia. Abdel-Aal et al. [23] studied the ground water quality for irrigation in two hundred and seventeen well water samples from central Saudi Arabia. They reported that water salinity ranged from 210 to 8200 ppm with an average of $2375 \mathrm{ppm}$. In general, the information on irrigation water quality classification for agriculture is inadequate as a guideline to optimize the use of groundwater in Saudi Arabia. With the expansion of agriculture lands, the agriculture related pollution sources, such as, pesticides, fertilizers, etc. are gradually contaminating groundwater, El Din et al. [24]. It is, therefore, important to monitor and protect the quality of groundwater from such pollutants. The previous studies concentrated on selected regions and the literature lacks reliable studies on groundwater quality in the southern region of Saudi Arabia, which is considered as one of the major agricultural region of the country. Accordingly, the main objective of this study is to evaluate the ground water quality of the Najran region for irrigation on the basis of chemical composition. Also, to show the effect of excessive extraction of groundwater resources on the environment and their resulting problems suffered in the number of wells and farms abandoned after 20-30 years of use in the Najran region (NCHRD [25]).

\section{Materials and methods}

\subsection{Description of the studied area}

Najran region is semi-mountainous, and located about 980 kilometers from Riyadh region, in the south-western of Saudi Arabia (mean altitude $1250 \mathrm{~m}$ above sea level). The region is bordered by the vast Rub Al-Khali desert in the east, the mountainous Assir region in the west and Republic of Yemen in the south. Wadi Najran flows from west to east where the studied wells were located in areas dominated by fertile agriculture lands. Most towns and villages of Najran are located along the banks of the wadi. The groundwater is available in a shallow alluvial aquifer along the Najran wadi. This aquifer is generally unconfined and the water table fluctuates rapidly in response to the local precipitation and season. Water pumped from wells was generally used for all purposes including domestic, drinking, and cooking, as well as irrigation. The annual average rainfall is $100-200 \mathrm{~mm}$.

\subsection{Water samples and methods of analysis}

Forty three tube well water samples were collected from different locations to represent the agricultural areas located along the banks of Wadi Najran. The 
water samples were collected for analysis from the delivery pipe of the pumps in clean agene sample bottles after running for at least five hours and then the bottles were sealed airtight. Water samples were analyzed as follows; electrical conductivity $\left(\mathrm{Ew}_{\mathrm{e}}\right)$ and $\mathrm{pH}$ of water were determined using standard Electrical Conductivity meter (EC) and $\mathrm{pH}$ meter, respectively, according to Richards, 1954. Soluble calcium $(\mathrm{Ca})$ and magnesium $(\mathrm{Mg})$ were determined according to the procedure of Chapman and Pratt, 1961. Carbonate $\left(\mathrm{CO}_{3}\right)$, bicarbonate $\left(\mathrm{HCO}_{3}\right)$ and chloride $(\mathrm{Cl})$ were determined as recommended by Chapman and Pratt [26]. Sodium (Na) and potassium (K) were analyzed using a flame photometer. Nitrate $\left(\mathrm{NO}_{3}-\mathrm{N}\right)$ was measured using a spectrophotometer according to the method described by Hack, [27]. Also, discharges of the 43 selected tube wells were measured using digital flowmeter, and the daily times of irrigation for each pump were determined.

\section{The results and discussions}

Results of chemical analysis and the calculated water quality parameters are presented in tables 1 and 2. Data indicated that, salinity of the pumped water of the studied wells $\left(\mathrm{EC}_{\mathrm{w}}\right)$ expressed in $\mathrm{dSm}^{-1}$ covers the range of 0.35 to $5.99 \mathrm{dSm}^{-1}$; i.e. 227 to $3834 \mathrm{ppm}$. The average salinity level was $1.95 \mathrm{dSm}^{-1}$; i.e. $1248 \mathrm{ppm}$. These data indicated high variations between the studied wells. Its shows also that application of the relatively high salt content water will add seasonally relatively high quantities of soluble salts to the soil. In that respect Abdel-Aal et al. [23] reported that using water with $2375 \mathrm{ppm}$ salts in the central region will deposit between 16.6 and $83 \mathrm{t} \mathrm{ha}^{-1}$ of salt per season for wheat and alfalfa cultivation, respectively. There are several sources, which might have contributed to the high salt concentration values in some of the studied wells. These sources are over-exploitation and excessive pumping, heavy application of inorganic fertilizers, organic amendments and low efficiency irrigation management. The rise in salt contents of well waters by excessive pumping is a phenomenon observed generally in the region. According to the recommendations of the United States Salinity Laboratory (USSL) guideline, Richards [2], the suitability of the studied well waters is saline to moderate saline water. Previous studies on the quality of irrigation water of the central Saudi Arabia, Abdel-Aal et al. [23] indicated that no water salinity ranged from 210 to $8200 \mathrm{ppm}$. Application of low quality irrigation water to the soil will increase the concentration of soluble salts in the root zone. Its was noticed that with reasonable good irrigation practices the salt content of the saturation extract of soil is 1.5 to 3 times salt content of the irrigation water. Moreover, leaching with ordinary irrigation methods decreases salt accumulation but does not eliminate such accumulation. On the other hand, According to the recommended levels in the guideline of the world health organization (WHO) [28] for salinity of drinking water about $48.8 \%$ of the wells had salinity values above the WHO standard of $1000 \mathrm{ppm}$. 
Table 1: Chemical composition of irrigation groundwater for the studied wells from the Najran region*

\begin{tabular}{|c|c|c|c|c|c|c|c|c|c|c|}
\hline Well No. & $\left|\begin{array}{c}E C w \\
(d S m-1)\end{array}\right|$ & $\mathbf{p H}$ & $\begin{array}{c}\text { TDS } \\
(\mathbf{p p m})\end{array}$ & $\begin{array}{c}\mathrm{Ca} \\
(\mathrm{meq} / \mathrm{l})\end{array}$ & $\begin{array}{c}\mathrm{Mg} \\
(\mathrm{meq} / \mathrm{l})\end{array}$ & $\begin{array}{c}4 \mathrm{Na} \\
(\mathrm{meq} / \mathrm{l})\end{array}$ & $\begin{array}{c}\mathrm{K} \\
(\mathrm{meq} / \mathrm{l}))\end{array}$ & $\begin{array}{c}\text { Cl } \\
(\mathrm{meq} / \mathrm{l})\end{array}$ & $\begin{array}{l}\mathrm{HCO}_{3} \\
(\mathrm{meq} / \mathrm{l})\end{array}$ & $\begin{array}{l}\mathrm{NO}_{3}-\mathrm{N} \\
(\mathrm{meq} / \mathrm{l})\end{array}$ \\
\hline 1 & 0.4 & 7.26 & 227 & 48.4 & 12.6 & 11.3 & 3.1 & 74.6 & 108.7 & 0.3 \\
\hline 2 & 0.5 & 7.3 & 339 & 65.3 & 18.8 & 25.5 & 3.5 & 74.6 & 112.2 & 0.5 \\
\hline 3 & 0.6 & 7.32 & 349 & 69.5 & 20.2 & 27.5 & 3.6 & 94.7 & 123.2 & 0.8 \\
\hline 4 & 0.6 & 7.35 & 355 & 71.6 & 20.3 & 27.8 & 4 & 106.5 & 124.4 & 0.8 \\
\hline 5 & 0.6 & 7.37 & 363 & 73.7 & 22.9 & 29.5 & 4 & 112.4 & 125.7 & 1.1 \\
\hline 6 & 0.6 & 7.38 & 365 & 73.7 & 24.1 & 30.3 & 4.3 & 142 & 128.1 & 1.4 \\
\hline 7 & 0.6 & 7.44 & 388 & 88.4 & 25.4 & 31.5 & 4.4 & 142 & 136.6 & 1.4 \\
\hline 8 & 0.6 & 7.45 & 408 & 88.4 & 26.6 & 32.5 & 4.4 & 142 & 142.7 & 1.5 \\
\hline 9 & 0.7 & 7.45 & 463 & 96.8 & 28 & 32.5 & 4.4 & 145.7 & 142.7 & 1.6 \\
\hline 10 & 0.8 & 7.46 & 496 & 98.9 & 29.2 & 32.8 & 4.5 & 177.5 & 150.1 & 1.7 \\
\hline 11 & 0.8 & 7.46 & 522 & 101.7 & 30.4 & 35 & 4.6 & 177.5 & 151.3 & 2.7 \\
\hline 12 & 0.8 & 7.48 & 534 & 115.8 & 30.5 & 36.3 & 4.6 & 177.5 & 153.7 & 2.7 \\
\hline 13 & 0.9 & 7.48 & 543 & 115.8 & 30.5 & 38.3 & 4.6 & 195.3 & 154.9 & 3 \\
\hline 14 & 0.9 & 7.48 & 580 & 117.9 & 34.4 & 42.3 & 4.7 & 195.3 & 156.2 & 3.7 \\
\hline 15 & 1.0 & 7.48 & 609 & 120 & 35.5 & 43.3 & 4.8 & 266.3 & 156.2 & 3.9 \\
\hline 16 & 1.0 & 7.51 & 621 & 120 & 35.5 & 43.5 & 5.7 & 266.3 & 157.4 & 5.0 \\
\hline 17 & 1.0 & 7.53 & 637 & 122.1 & 38.1 & 52 & 5.7 & 266.3 & 158.6 & 5.1 \\
\hline 18 & 1.2 & 7.54 & 759 & 128.4 & 38.1 & 54 & 6.5 & 284 & 162.3 & 5.2 \\
\hline 19 & 1.3 & 7.54 & 848 & 130.5 & 40.6 & 70 & 6.8 & 284 & 163.5 & 6.4 \\
\hline 20 & 1.4 & 7.54 & 884 & 155.8 & 49.6 & 78 & 7.2 & 284 & 167.1 & 6.5 \\
\hline 21 & 1.5 & 7.56 & 940 & 157.9 & 56.9 & 78.8 & 7.4 & 301.8 & 168.4 & 7.2 \\
\hline 22 & 1.5 & 7.56 & 943 & 166.3 & 59.6 & 80.5 & 7.6 & 301.8 & 170.8 & 7.2 \\
\hline 23 & 1.8 & 7.57 & 1170 & 210.5 & 59.7 & 80.5 & 7.9 & 355 & 172 & 7.6 \\
\hline 24 & 2.0 & 7.57 & 1252 & 218.9 & 62.1 & 100.3 & 7.9 & 355 & 173.2 & 7.9 \\
\hline 25 & 2.1 & 7.58 & 1325 & 225.3 & 63.4 & 101.5 & 8 & 408.3 & 175.7 & 8.6 \\
\hline 26 & 2.1 & 7.59 & 1344 & 237.9 & 63.6 & 103.8 & 8.1 & 426 & 176.6 & 8.6 \\
\hline 27 & 2.1 & 7.6 & 1363 & 240 & 64.7 & 104.3 & 8.2 & 426 & 176.9 & 8.7 \\
\hline 28 & 2.2 & 7.6 & 1408 & 256.8 & 64.7 & 105 & 8.8 & 426 & 180.6 & 9.4 \\
\hline 29 & 2.2 & 7.61 & 1414 & 256.8 & 67.3 & 111.3 & 9.5 & 426 & 180.6 & 9.8 \\
\hline
\end{tabular}


Table 1: $\quad$ Continued.

\begin{tabular}{|c|c|c|c|c|c|c|c|c|c|c|}
\hline 30 & 2.2 & 7.62 & 1427 & 261.1 & 73.8 & 114 & 9.6 & 461.5 & 186.7 & 9.8 \\
\hline 31 & 2.3 & 7.64 & 1491 & 265.3 & 76.1 & 130.3 & 9.6 & 514.8 & 190.3 & 10.1 \\
\hline 32 & 2.4 & 7.64 & 1517 & 267.4 & 76.2 & 131.3 & 9.6 & 532.5 & 191.5 & 10.7 \\
\hline 33 & 2.4 & 7.65 & 1523 & 269.5 & 81.3 & 137.3 & 10.5 & 532.5 & 194 & 14.6 \\
\hline 34 & 2.5 & 7.65 & 1619 & 271.6 & 82.5 & 159.5 & 10.6 & 550.3 & 195.2 & 15.2 \\
\hline 35 & 2.6 & 7.66 & 1645 & 282.1 & 95.3 & 172.8 & 11.2 & 603.5 & 203.7 & 15.4 \\
\hline 36 & 3.1 & 7.66 & 1939 & 313.7 & 110.5 & 173 & 11.8 & 642.6 & 207.4 & 15.6 \\
\hline 37 & 3.6 & 7.67 & 2330 & 317.9 & 116.9 & 175.8 & 12.1 & 798.8 & 214.7 & 16.0 \\
\hline 38 & 4.1 & 7.67 & 2605 & 334.7 & 128.2 & 252.5 & 12.7 & 869.8 & 229.4 & 20.1 \\
\hline 39 & 4.1 & 7.68 & 2630 & 353.7 & 130.7 & 305 & 13.2 & 1011.8 & 230.6 & 24.4 \\
\hline 40 & 4.1 & 7.72 & 2650 & 406.3 & 154.9 & 345 & 13.3 & 1047.3 & 261.1 & 27.9 \\
\hline 41 & 5.2 & 7.73 & 3347 & 429.6 & 192.2 & 462.5 & 14.1 & 1171.5 & 279.4 & 32.0 \\
\hline 42 & 5.6 & 7.79 & 3597 & 482.1 & 212.2 & 567.5 & 15.1 & 1278 & 323.3 & 32.4 \\
\hline 43 & 6.0 & 7.8 & 3834 & 534.7 & 258.4 & 580 & 26.8 & 1544.3 & 391.6 & 33.1 \\
\hline Average & 1.9 & 7.6 & 1246.6 & 203.8 & 68.4 & 124.3 & 8.1 & 432.4 & 180.2 & 9.5 \\
\hline
\end{tabular}

Analysis of soluble cations and anions indicated that, the dominant cation was $\mathrm{Ca}$ with an average value of $203.8 \mathrm{ppm}$ for the forty three well water samples followed by $\mathrm{Na}$ and $\mathrm{Mg}$ with an average value of 124.33 and $68.43 \mathrm{ppm}$ respectively, (Table 1). The only exception was observed in the highest salt concentration water wells where $\mathrm{Na}$ was the dominant cation followed by $\mathrm{Ca}$ and Mg (well No. 41, 42 and 43). Potassium (K) was present in relatively low concentrations, but its concentration was increased with the increase in $\mathrm{EC}_{\mathrm{w}}$ values. The dominant anion was $\mathrm{Cl}$ followed by $\mathrm{HCO}_{3}^{-}$, While $\mathrm{CO}_{3}{ }^{2-}$ was absent in all the studied samples. The average concentrations were 432.41 and 180.22 ppm for $\mathrm{Cl}$ and $\mathrm{HCO}_{3}$ anions respectively.

It appears that chloride concentrations increased gradually with the increase in salt contents of the well water. As mentioned by Ayers [1] water with less than $140 \mathrm{ppm} \mathrm{Cl}$ sensitive plants usually show slight to moderate injury. Severe problems are found at $\mathrm{Cl}$ concentrations greater than $350 \mathrm{ppm}$. Therefore, it should be noticed that the high $\mathrm{Cl}$ water may cause severe problems for the sensitive and moderately tolerant plants particularly trees and woody ornamentals. The data also indicated that, $\mathrm{pH}$ values ranged from 7.88 to 7.80 with an average value of 7.55. It seems that, the obtained $\mathrm{pH}$ values did not show significant fluctuations between all the studied wells.

Examining the data for the two sodicity parameters Adj. SAR and RSC were calculated using the procedures presented by Ayers [1]; Wilcox [29] and FAO [30] as shown in Table 2. It can be observed that the former covers the range of 0.525 to 17.22 with an average of 4.17 , whereas the latter ranges between -1.69 
to -41.85 with an average of -12.94 meq/l. It appears that most of the studied water samples have Adj SAR values less than 6.0 which indicate no problems with either sodium or soil permeability. As the majority of the soils of Wadi Najran are alluvium soils (i.e. loamy to sandy loam or sandy soils), the sodicity build up is not expected as a result of using these waters to irrigate such soils. This conclusion was also supported by the very low RSC values of all the studied samples. The RSC values (Table 2) are generally low and shows such values are mostly desired.

Table 2: $\quad$ Water quality parameters for the studied well water samples.

\begin{tabular}{|c|c|c|c|c|c|c|c|c|}
\hline $\begin{array}{l}\text { Well } \\
\text { No. }\end{array}$ & $\begin{array}{c}\mathbf{A d j}^{*} \\
\text { SAR }^{*}\end{array}$ & RSC $^{* * *}$ & $\begin{array}{l}\text { Well } \\
\text { No. }\end{array}$ & $\begin{array}{c}\text { Adj } \\
\text { SAR }^{*}\end{array}$ & $\mathbf{R S C}^{* *}$ & $\begin{array}{l}\text { Well } \\
\text { No. }\end{array}$ & $\begin{array}{c}\mathbf{A d j} \\
\text { SAR }^{*}\end{array}$ & RSC $^{* * *}$ \\
\hline 1 & 0.53 & -1.69 & 18 & 2.46 & -6.94 & 35 & 5.33 & -18.71 \\
\hline 2 & 1.10 & -2.99 & 19 & 2.46 & -7.24 & 36 & 6.33 & -21.77 \\
\hline 3 & 1.30 & -3.14 & 20 & 2.56 & -9.18 & 37 & 7.86 & -22.12 \\
\hline 4 & 1.34 & -3.23 & 21 & 2.78 & -9.88 & 38 & 8.53 & -23.58 \\
\hline 5 & 1.34 & -3.54 & 22 & 3.29 & -10.49 & 39 & 9.34 & -24.80 \\
\hline 6 & 1.35 & -3.60 & 23 & 3.62 & -12.69 & 40 & 9.73 & -28.94 \\
\hline 7 & 1.40 & -4.30 & 24 & 3.62 & -13.29 & 41 & 10.97 & -32.92 \\
\hline 8 & 1.40 & -4.30 & 25 & 3.88 & -13.67 & 42 & 14.64 & -36.39 \\
\hline 9 & 1.47 & -4.83 & 26 & 3.98 & -14.30 & 43 & 17.22 & -41.85 \\
\hline 10 & 1.70 & -4.92 & 27 & 3.98 & -14.49 & \multirow{3}{*}{ Mean } & \multirow{3}{*}{4.17} & \multirow{3}{*}{-12.94} \\
\hline 11 & 1.70 & -5.14 & 28 & 3.95 & -15.27 & & & \\
\hline 12 & 1.71 & -5.81 & 29 & 4.43 & -15.49 & & & \\
\hline 13 & 1.72 & -5.79 & 30 & 4.28 & -16.15 & & & \\
\hline 14 & 1.93 & -6.21 & 31 & 4.54 & -16.49 & & & \\
\hline 15 & 1.98 & -6.40 & 32 & 4.54 & -16.58 & & & \\
\hline 16 & 2.42 & -6.38 & 33 & 4.58 & -17.08 & & & \\
\hline 17 & 2.42 & $\begin{array}{l}-6.69 \\
\end{array}$ & 34 & 4.83 & -17.26 & & & \\
\hline
\end{tabular}

*Adjusted Sodium Adsorption Ratio (Adj. SAR) = SAR $\left[1+\left(8.4-\mathrm{pH}_{\mathrm{C}}\right)\right]$; where: $p H c=\left(p K_{2}^{1}-p K_{c}^{1}\right)+p(C a+M g)+p A l K ; \quad\left(\mathrm{pK}_{2}^{1}-\mathrm{pK}_{\mathrm{c}}^{1}\right)$ is obtained from $(\mathrm{Ca}+\mathrm{Mg}+\mathrm{Na})$;

$\mathrm{p}(\mathrm{Ca}+\mathrm{Mg})$ is obtained from $(\mathrm{Ca}+\mathrm{Mg})$; pAlk is obtained from $\mathrm{CO}_{3}+\mathrm{HCO}_{3}$

$* *$ Residual Sodium Carbonate $(\mathrm{RSC})=\left(\mathrm{CO}_{3}+\mathrm{HCO}_{3}\right)-(\mathrm{Ca}+\mathrm{Mg})$.

Concentration of nitrate $\left(\mathrm{NO}_{3}-\mathrm{N}\right)$ ranged from 0.3 to $33.1 \mathrm{ppm}$ with an average value of $9.48 \mathrm{ppm}$. The levels of $\left(\mathrm{NO}_{3}-\mathrm{N}\right)$ in the studied well waters varied significantly from one well to another. But, in view of the WHO [28] which put the limit of $45 \mathrm{ppm}$ nitrates as the highest tolerable nitrate content in drinking water, it can be recognized that all the tested wells have a concentrations less than $45 \mathrm{ppm}$ (as shown in table 1). There are several potential sources, which might have contributed to elevated levels of $\mathrm{NO}_{3}-\mathrm{N}$ in some wells, including human and animal wastes, nitrogenous fertilizers, organic manures and domestic wastes.

The discharges for 43 tube wells (Fig. 1) and daily irrigation times (Fig. 2) varied from one farm to another as shown in the figures. The discharges ranged between 23 to $65 \mathrm{~m}^{3} / \mathrm{hr}$ and the times of irrigation ranged between 2 to 
20.3 hour/day. It should be mentioned that the groundwater was the only source of irrigation and the surface irrigation was the predominant irrigation method used in the region. Also, it was observed during the visits to the selected farms that most soils were sandy to loamy sands and irrigation channels were not lined and farm lands were not properly leveled. Also, it was noticed that farmers had little knowledge of crop water requirements, and there was excessive water applied during every irrigation. These factors were responsible for heavy water losses during conveyance and field application, and this made the existing annual groundwater discharge exceeded the limited annual recharge. This excessive withdrawal of groundwater lowered the groundwater levels, increased groundwater salinity (fig. 3) and hence affected the discharge of the tube wells in operation, and in fact some of these tube wells dried up and ultimately a number of the farms were abandoned each year in the Najran region as shown in figure 4. The number of tube wells in the Narjan region was over 4000 wells 20 years ago. Nowadays, the wells still in operation to pump water for irrigation in the region have decreased to less than 2000 (NCHRD [25]).

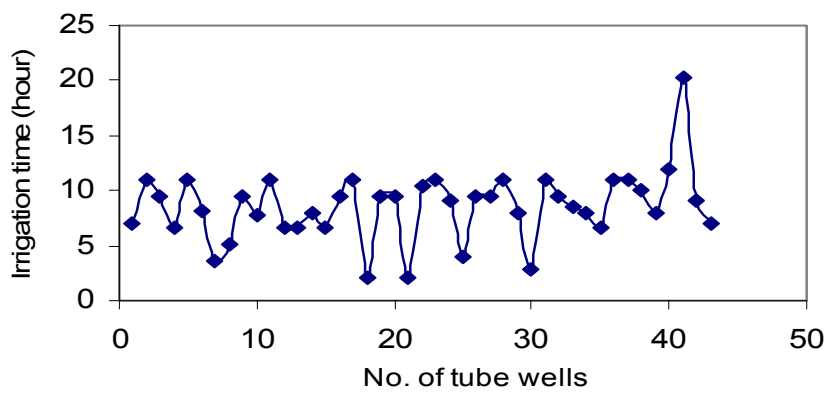

Figure 1: Variation of discharges from 43 tube wells.

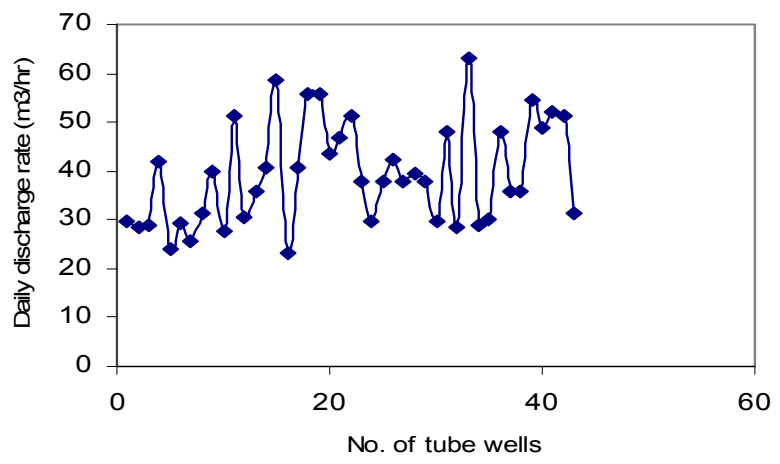

Figure 2: The times of daily irrigation for 43 tube wells. 


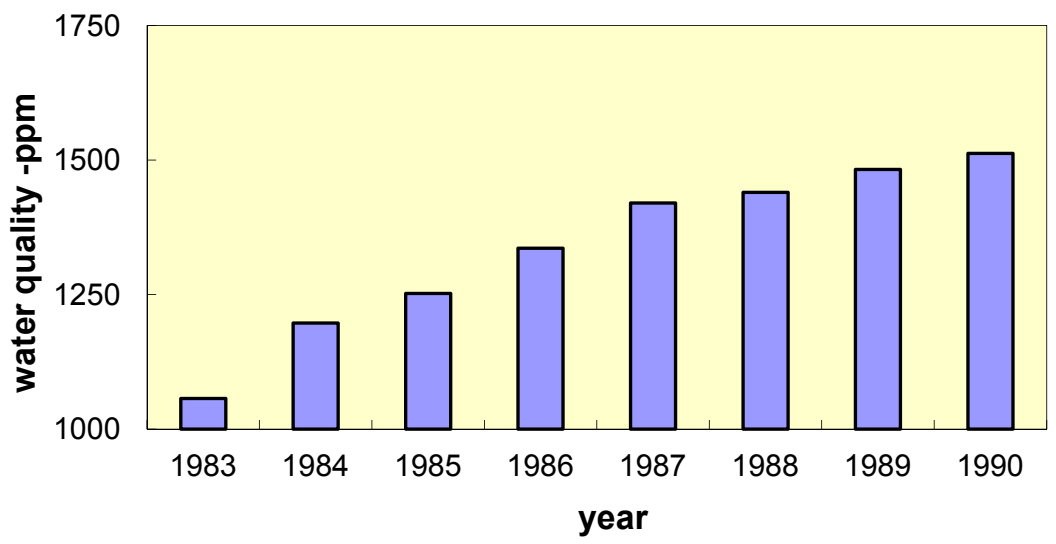

Figure 3: The increase of groundwater salinity caused by excessive pumping of groundwater.
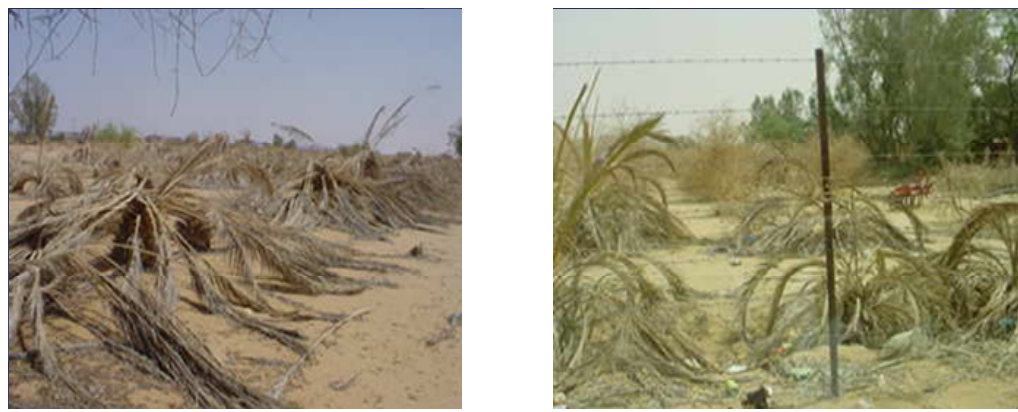

Figure 4: Farms of date palm and citrus trees abandoned, as a result of groundwater depletion.

\section{Conclusions}

In the light of the preceding results and discussion, the following conclusion can be drawn. The survey of the quality of 43 tube well waters in the Najran region has demonstrated high levels of some indicators measured. Elevated concentrations of total dissolved salts were observed and $48.8 \%$ of the wells had salinity levels values above the WHO recommended values. A wide variation of nitrate concentrations was detected, and all the tested wells have lower concentrations lower than $45 \mathrm{ppm}$.

Also, it was found that in the Najran region a large fraction of farms (more than $35 \%$ ) which have been equipped with wells and irrigation systems have abandoned business and farming as a result of groundwater depletion, because of the increased areas irrigated and hence, the number of tube wells and also, poor irrigation water management. The excessive extraction of groundwater resources 
have caused that water for human consumption and agriculture has become an increasingly scarce, which resulted in detrimental effects on the environment by desertification (figure 3) and climate change, especially in Saudi Arabia experiencing drought and hot and dry climate.

Therefore, water quality is a major concern in the region and Groundwater resources can deteriorate as a result of over-exploitation or, when used intensively pesticides, insecticides and without the necessary precautions. In view of the present study, it is suggested that optimizing the application of organic and inorganic fertilizers, and better management of the groundwater, could control the degradation in the quality of some well waters in the Najran region. The need for further investigation of more well waters and on a routine of bases is imperative to help control sources of water management and accurate evaluation of their magnitude and also, to reduce the number of the abandoned farms each year in the Najran region.

\section{References}

[1] Ayers, R. S. 1977. Quality of water for irrigation. J. of irrigation and Drainage Division. ASCE., vol. 103: 135-154.

[2] Richards, L. A. (ed.). 1954. Diagnosis and Improvement of saline and alkali soils. USDA. Agric. Hand book No. 60. Washington, D. C., pp. 160.

[3] Doneen, L. D. 1958. Studies of water quality criteria. Quality of water for irrigation Proc., Water resources center, UC. Davis, Calif., U.S.A.

[4] Rhoades, J. D. 1972. Quality of water for irrigation. Soil Science J., vol. 113: 277-284.

[5] Oster, J. D. and Rhoades, J. D. 1977. Various indices for evaluating the effective salinity Conference, August 1977, Texas Technical University, Lubbock.

[6] Oster, J. D. and Schroer, F. W. 1979. Infiltration as influenced by irrigation water quality. Soil Science Society of America Proceedings, vol. 43: 44-47.

[7] Bielorai, H., Shalhevet, J. and Levy, Y. 1983. The effect of high sodium irrigation water on soil salinity and yield mature grapefruit orchard. Irrigation Science, vol. 4:255-266.

[8] Bhivare, V. N. and Nimbalkar, J. D. 1984. Salt stress effects on growth and mineral nutrition of French beans. Plant and Soil, vol. 80:91-98.

[9] Moolman, J. H. 1985. The effect of a change in irrigation water quality on the salt load of the deep percolate of a saline sodic soil: a computer simulation study. Irrigation Science, vol. 6:19-28.

[10] Al Ruwaih, F., Sayed, S. and Al-Rashed, M. 1998. Geological controls on water quality in arid Kuwait. J. of Arid Environments, vol. 38(2):187-204.

[11] Al-Kharabshesh, A. 1999. Ground-water quality deterioration in arid areas: a case study of the Zerqa river basin as influenced by Khirbet Es-Samra waste water (Jordan). J. of Arid Environments, vol. 43(3):227-239.

[12] Hamza, A. G., Louty, M. A. Mustafa, A. M. and Hassan, M. M. A. 1975a. Riyadh water and its utilization as mineral water, part II: Anion 
determination. Bulletin, Faculty of science, Riyadh University, vol. 7: 257261.

[13] Ayed, I. A. and Mashhady, A. S. 1982. Irrigation water and patterns of soil salinization of Deirab. J. Coll. Agric. King Saud Univ., vol. 4: 139-144.

[14] Mashhady, A. S. and Yousef, A. F. 1983. Evaluation of Al-Qatif irrigation water based on recent concepts of quality appraisal. J. Coll. Agri. King Saud Univ., vol. 5:29-34.

[15] Etewy, H., Asseed, M. Al-Barrack, S. and Turjoman, A. M. 1983. Water quality and soil characteristics as related to irrigation and drainage in AlHasa area. Saudi Biological Society Proc. $6^{\text {th }}$ Conf. 489-512.

[16] Mee, J. M. 1983. Saudi ground water chemistry and its significance. Arab Gulf J. Sci. Res., vol. 1: 113-120.

[17] Al-Omran, A. M. 1987. Evaluation of some irrigation water in central region of Saudi Arabia. J. Coll. Agric. King Saud Univ., vol. 9(2):363-369.

[18] Bazuhair, A. S. and Alkaff, A. 1989. Evaluation of ground water quality in wadi Al-Yamaniyah, Saudi Arabia. Arab Gulf Journal of Scientific Research, vol. 7: 21-38.

[19] Hussain, G. and Sadiq. M. 1991. Metal chemistry of irrigation and drainage waters of Al-Hassa Oasis of Saudi Arabia and its effects on soil properties. Water, Air and Soil Pollution 57/58: 773-783.

[20] Al-Ghobari, H. M. 1992. Influence of Irrigation Water Quality on Soil Infiltration. Irrigation Science 14:15-19.

[21] Al-Jaloud, A. A. and Hussain, G. 1993. Water quality of different aquifers in Saudi Arabia and its predictive effects on soil properties. Arid soil research and rehabilitation, vol. 7:85-101.

[22] Al-Jaloud, A. A. 1999. Use of Saline Water for Irrigation in Saudi Arabia, Journal of Mediterranean Ecology, Vol. 2-106-117.

[23] Abdel-Aal, S. I., Sabrah, R. Rabie, R. K. and Abdel Magid, H. M. 1997. Evaluation of ground water quality for irrigation in center Saudi Arabia. Arab Gulf J. Sci. Res., vol.15 (2): 361-377.

[24] El Din, M. N., Madany, I. M. Tayaran, A. Al-Jubair, A. H. and Gomaa, A. 1993. Trends in water Quality of some wells in Saudi Arabia. Sci. Total Environ., vol.154:110-122.

[25] National Center for Horticultural Research and Development, Najran, Ministry of Agriculture and Water. Annual technical report (1987-2005) in co-operation with Food and Agriculture Organization of United Nation (FAO), UTFN/006/ SAU.

[26] Chapman, H. D. and Pratt, P. F. 1961 Methods of Analysis for Soils, Plants and water. Univ. California, Berkeley, CA., USA., pp. 1-309.

[27] Hack, D.R. 1998. Analysis of nitrate-nitrogen and Cadmium Reduction Method and Programme No. 2520. pp. 495-502.

[28] World Health Organization (WHO). 1984. Guidelines for Drinking Water Quality, Vol. 2. Health criteria and other supporting info.

[29] Wilcox, L.V. U.S. 1966. Salinity Laboratory, mimeo 30 December.

[30] FAO/Unesco. 1973. Irrigation, Drainage and Salinity - An International Sourcebook. Paris, Unesco/Hutchinson, London, 510 p. 